\title{
GEOGRAPHY OF SOCIETAL TRANSFORMATION: GENERAL QUESTIONS OF STUDY
}

M. Hampl: Geography of Societal Transformation: General Questions of Study. Geografie-Sborník CGS, 101, 2, pp. 82 - 91 (1996). - The paper is devoted both to empirical generalization of contemporary transformation in the Czech Republic and to the theoretical discussion of selective problems of geographical cognition. Stress is put upon the question of geographical regularities, relation between social and geographical structures and the problem of uneven development.

KEY WORDS: Societal transformation - geographical regularities - uneven development.

The author would like to thank Grant Agency of Czech Republic for support of the grant no. 30258 (Theory of regional differentiation of Societal Development) under which this contribution was prepared.

\section{Introduction}

The transformation processes in post-totalitarian countries have become an important theme in possibly all social sciences, social geography included. Changes in the locational attractiveness of countries and regions, as well as the territorial differences in the dynamics and successfulness of transformation processes certainly deserve increased interest in geographical study. Moreover, contemporary social geography is classifying itself clearly among social sciences, so the interest in internal societal problems and their solutions becomes primary. This is also linked to the disillusionment caused by problematic results of "positivistic" geography.

There is a question, however, whether repeated conceptual imports from other sciences may help to solve epistemological problems of geography. The present plurality of paradigms amplified by post-modern admiration for disorder may express adequately reached knowledge of socio-geographical reality. In that case, though, it only one account of an extraordinary complex reality. This may be why much research continues to have either a mainly descriptive character or a general but too speculative orientation. An eloquent example is the geographical study of societal transformation (cf. e.g. Carter, F. W., Maik, W. eds., 1995). This serves as a starting point for the discussion of general questions about geographical study.

The first aim of this contribution is a theoretical discussion about geographical aspects of the study of societal transformation. The discussion is understood as a certain superstructure above an empirical depiction of the Czech reality, though already in a generalized form. These "primordial" empirical generalizations of up-to-date transformation results should lend support above all to the existence of geographical regularities. These regularities are thought of as a stochastic or "frame" type, and do not exclude secondarily 
important peculiarities of the structures and evolution processes in individual regions or localities. In the second part, the discussion is concentrated on the problem of relation or of connection between the social and the geographical organizations. The duality in understanding this relation is a fundamental problem of a subject classification of social geography. This duality may be expressed as whether the subject here is a transformation of geographical organization of society, or the geographical organization of societal transformation. Finally, the third part of the paper deals with the question of the socalled uneven (particularly territorial) societal development. This problem may be considered as a key problem for the establishment of assessment criteria in case of the regional development and regional policy. It is also important for the assessment of "great problems" such as questions of social justice, justifiability of societal development regulations, relations between principles of solidarity and meritocracy, etc. In that case also, duality in understanding uneven development appears: is it a question of societal decision and "social justice" or is it an objective regularity?

\section{Geographical differentiation of contemporary societal transformation in the Czech Republic}

The results of many empirical analyses of transformation changes enable one to make generalized assessments (cf. also $\mathrm{Hampl}$, M. et al., 1996, $\mathrm{Hampl}$, M., 1996). These suggest a hierarchy of factors of geographical differentiation of transformation changes and corresponding regularities in this differentiation. The consequence of mentioned assessments has a special meaning in itself, because it expresses their importance succession. With regard to primordial nature of the order in geographical reality, i.e. to regularly asymmetric differentiation of this reality (Hampl, M., 1994, 1995), the problem consists in the establishment of importance consequence of geographical differentiations.

The most fundamental factor is the hierarchical organization of the sociogeographic system, not only at the level of settlements but also at the level of regions. In the transformation period, polarization between metropolitan areas and other areas increased, and is still increasing. In a simplified way, three hierarchical levels can be thus distinguished at a regional (supra-district) scale: Prague metropolitan area, other metropolitan areas, and relatively rural (non-metropolitan) areas. The changes in the settlement hierarchy at local levels are of secondary importance. It must be admitted that sharp differences in territorial settlement intensity and in resulting functional specialization of settlements does exist here. However, these differences are not new. In addition, they have more limited influence on the quality of life of the population because of the intensity of commuting between the towns and the country. Important differences can be found in the economic situation of municipalities, though (cf. Blažek, J., 1994). The reason for the integral influence of settlement and regional hierarchy on the course and results of transformation lies in correlation between size and qualitative differentiation of settlements, resp. of urban regions. Examples include the increases in diversification of economic base, share of non-productive activities, education level of the population, and increases in provision with social and technical infrastructure, etc.

The second key factor is locational and especially macro-locational attractiveness. Its role was fundamentally increased by the "opening up" of the 
Czech economy and society to foreign countries. At the same time, its polarization was "reversed", due to the change in geo-political and geo-economic position of the Czech Republic. Its important application cannot be, though, explained only by the factor of distance from developed countries or regions. Fundamental societal changes in Central and Eastern Europe have made possible the revitalization of the historically rooted links between East and West. The correlation between cultural and distance zonation is proof of both force of evolutional inertia and integral - even though gradually developed unity of Europe. This too, is a case of hierarchical polarization of the centreperiphery type but at a higher scale - the continental level. That is why the results of this polarization are best seen at the supra-national level (see also division of the Czechoslovakia). In the context of the Czech Republic, these consequences are important for macro-regional differentiation, especially in non-metropolitan areas.

The third important but selectively occurring factor is economic specialization of territorial units. Pronounced specialization brings increased sensitivity to transformation changes, both in a positive and negative sense. In the second case the most important examples are both basin areas - North Bohemian and Ostrava areas (the latter with negative influence of an unfavourable location). The disadvantages of agricultural areas are more limited in their manifestation (often due to the compensating role of favourable location). On the other hand, positive consequences of transformation can be found in the areas attractive for the tourism and recreation industry (e.g. Český Krumlov region) or in micro-regions where industrial specialization attracts foreign investors (e.g. Mladá Boleslav region).

By combining these conditions of the geographical differentiation of transformation processes, a simple typology of districts expressing the most important features of a newly created regional structure of the Czech Republic can be elaborated. There are 5 categories in this typology: Prague metropolitan area - basin (metropolitan) areas - other metropolitan areas - Western nonmetropolitan areas - Eastern non-metropolitan areas. Table 1 shows characteristics of the categories. The assessment of the order or rank of the categories from the point of view of maturity and "transformation successfulness" finds correlation in almost all characteristics (see order referred to above) with the exception of the basin areas. These represent special problem units which possess notable economic power, but "restrained" economic development connected to serious social and economic unbalances. This is reflected in their ambiguous assessment according to selected characteristics.

Data in Table 1 lend support to the above formulated generalizations and help depict regularities in the basic order of regional differentiation. But with the gradual increase of territorial and content detailedness of assessment regularities in partial geographical structures "disappear". In this sense, the nature of order in geographical reality can be justifiably characterized as a hierarchy of differentiations oriented primarily from the whole to the parts i.e. "from the top". Basic differentiations of geographical systems show regular organization, which is "completed" by a variability of geographical phenomena with regard to other features, secondary by their importance. As an example, although hierarchic size differentiation of settlements occurs in every settlement system, it is almost impossible to find regular space configurations in settlement organization predicted by central place theory. Organization of geographical reality must be thus necessarily understood as an integral differentiation in coexistent combination of diverse phenomena, a 
Table 1 - Basic characteristics of district categories

\begin{tabular}{|c|c|c|c|c|c|c|c|c|c|c|c|}
\hline \multirow{3}{*}{ Category } & \multicolumn{4}{|c|}{$\begin{array}{l}\text { Share on the total } \\
\text { of } \mathrm{CzR} \text { in \% }\end{array}$} & \multicolumn{7}{|c|}{$\begin{array}{l}\text { Characteristics of transitional changes } \\
\left.\text { (per hab., } C_{2} R=100\right)\end{array}$} \\
\hline & \multirow[t]{2}{*}{ area } & \multirow[t]{2}{*}{$\begin{array}{l}\text { popu- } \\
\text { lation } \\
1995\end{array}$} & \multirow[t]{2}{*}{$\begin{array}{l}\text { jobs } \\
1993\end{array}$} & \multirow{2}{*}{$\begin{array}{c}\text { jobs } \\
\text { in } \\
\text { bank- } \\
\text { ing } \\
1993\end{array}$} & \multirow{2}{*}{$\begin{array}{c}\text { Tan- } \\
\text { gible } \\
\text { invest- } \\
\text { ments } \\
1993\end{array}$} & \multirow[t]{2}{*}{$\begin{array}{c}\text { Tax } \\
\text { inco- } \\
\text { mes } \\
1994\end{array}$} & \multirow{2}{*}{$\begin{array}{c}\text { Private } \\
\text { entre- } \\
\text { pre- } \\
\text { neurs } \\
1994\end{array}$} & \multirow[t]{2}{*}{$\begin{array}{c}\text { Unem- } \\
\text { ployed } \\
1995\end{array}$} & \multirow[t]{2}{*}{$\begin{array}{l}\text { Index } \\
\text { of jobs } \\
1993 / 91\end{array}$} & \multicolumn{2}{|c|}{$\begin{array}{l}\text { Average } \\
\text { salaries }\end{array}$} \\
\hline & & & & & & & & & & 1993 & $\begin{array}{c}\text { index } \\
1993 / 89\end{array}$ \\
\hline $\begin{array}{l}\text { Metropolitan } \\
\text { areas }\end{array}$ & 23,4 & 47,0 & 51,3 & 63,3 & 128 & 134 & 107 & 84 & 102 & 108 & 104 \\
\hline $\begin{array}{l}\text { in them: } \\
\text { Prague }\end{array}$ & 2,2 & 13,4 & 16,0 & 32,4 & 171 & 205 & 136 & 10 & 108 & 121 & 113 \\
\hline basin & 5,2 & 12,9 & 12,4 & 9,8 & 118 & 103 & 77 & 188 & 93 & 110 & 100 \\
\hline other & 16,0 & 20,7 & 22,9 & 21,1 & 108 & 107 & 106 & 68 & 104 & 98 & 99 \\
\hline $\begin{array}{l}\text { Non-metro- } \\
\text { politan areas }\end{array}$ & 76,6 & 53,0 & 48,7 & 36,7 & 75 & 70 & 94 & 114 & 98 & 93 & 97 \\
\hline $\begin{array}{l}\text { in them: } \\
\text { Western }\end{array}$ & 38,6 & 22,7 & 20,8 & 17,1 & 86 & 78 & 99 & 103 & 96 & 96 & 99 \\
\hline Eastern & 38,0 & 30,3 & 27,9 & 19,6 & 67 & 64 & 91 & 122 & 99 & 90 & 95 \\
\hline
\end{tabular}

Notes: Distribution of districts into the categories: Prague metropolitan area contains Praha, Praha-východ a Praha-západ; basin areas contain districts Chomutov, Most, Teplice, Ústí nad Labem, Ostrava, Karviná, Frýdek-Místek; other metropolitan areas contain districts České Budějovice, Plzeň-město, Plzeñ-jih, Plzeň-sever, Karlovy Vary, Liberec, Jablonec nad Nisou, Hradec Králové, Pardubice, Brno-město, Brno-venkov, Zlín and Olomouc. Other districts of Mid-Bohemian, South-Bohemian, West-Bohemian and NorthBohemian regions form Western non-metropolitan areas and other districts of EastBohemian, South-Moravian and North-Moravian regions form Eastern non-metropolitan areas. In the case of tangible investments their financial amount is assessed, in the case of tax incomes these are incomes of the municipalities and the districts from the salaries of employees and small entrepreneurs. Data about jobs 1991 originate from the Census 1991 and encompass all the jobs, similar data for 1989 and 1993 (including data about salaries) encompass only civilian sector, in 1993 without small enterprises (with 24 and less employees).

Sources: Census 1991; internal publications of the Czech Statistical Office: Employment and salaries 1989, Districts of the Czech Republic 1994, Selected indicators of the districts of the Czech republic in the 1st half-year 1995; Internal materials of the Ministry of Finance of the Czech Republic.

differentiation which is extremely asymmetric to the high occurrence of unfavourable combinations and the low occurrence of highly favourable combinations. The distance factor itself is applied only in a partial and modified way. The spatial organization of phenomena must be thus necessarily understood before all as an external expression of hidden nature, so its exact form is neither regular nor important (see also the application of realism: structures - mechanisms - events, Sayer, A., 1984).

In this context, a critique of positivist geography can be added. Its failure was not primarily a consequence of narrowing study to "the empirically found 
out and verified", but a consequence of inadequate reduction of the subject of geographical study (and thus also of appropriate empirical findings) to spatial structures. Although in the post-positivist period "the geographical" is again completed in content especially in connection with enforcement of contextual explanation (Hägerstrand, T., 1973, 1995, Thrift, N., 1983), stress is too much put on internal social relations, on mere spatial "constraint" of social integration in the frame of localities and regions.

\section{Duality in the conception of the relation between geographical and social reality}

In geographical studies dealing with societal problems two fundamental approaches and related thematic directions can be identified. First is an examination of geographical organization of society as a relatively autonomous structure conditioned both by an interaction of the society with its natural environment and by an "external" interaction of territorial societal subjects themselves (settlements, regions). In these interactions, the influence of a distance factor can be felt. Second is an examination of the situation and changes of economic, social and political conditions in various territorial units, i.e. an examination of the differentiating influence of geographical combinations of partial societal structures and processes. In this case the concept of the society is narrowed to its "internal" organization as is usual in social science research. The consequence of this is a usual assessment of geographical differentiation of the society only as a result of secondarily important or modifying application of specific conditions of external environment to the realisation of general tendencies formed by the principle of internal organization of society and its evolutional movement. As an example of these approaches is the interaction between the global and the local (see e.g. critical discussion in Sayer, A., 1991) or much contemporary geographical work about transformation processes in post-totalitarian countries.

Both approaches are of course justified and do not exclude each other. The thing is that the mentioned duality corresponds both to a relative autonomy of above characterized internal (societal in narrower sense) and external (geographical resp. ecologic) organization of the society and to their integral unity and correspondent mutual influencing. It is only the mutual combination of both approaches that can bring deeper and more complete knowledge of these problems. The geographical differentiation has an irreplaceable role in the development of the society as a source of significant evolution impetuses. Differences in external conditions of more narrowly defined societal system are at the same time not only random combinations of environmental factors but in the first place regular differentiation of the environment i.e. hierarchic (asymmetric) organization of mentioned combinations from the point of view of their favourableness. That is why fundamental features of geographical differentiation in transformation dynamics and successfulness of localities are regular. An example is the settlement and regional hierarchy or macro-locational zonation characterized above. Analogously, there can be expected regularities in geographical diffusions of changes. On the other hand, the "internal" movement of the society influences changes in its external organization both as regards transformation of functional specialization of localities and regions and changes in central functions and in regional importance of cities. 
It seems, however, that the contemporary orientation of human geography deviates from the discussed unification of both approaches of geographical examination of development of the society. An adoption of paradigms from social sciences leads understandably also to an adoption of problem themes and examination tasks, especially sociological and political ones. The situation is characterized by formation of two or three main types of approaches. These include: voluntarist approaches proceeding from the decisive role of activity of a human individual (e.g. behaviour geography); structuralist - functionalist or neo-marxist, stressing the role of societal organization (especially marxist geography); approaches trying to overcome traditional sociologic duality by means of a study of interaction between an individual and social organization - especially the theory of structuration (Giddens, A., 1984 and others) and realism (Bhaskar, R., 1979, Sayer, A., 1984). In all these cases the attention of geographical study is shifted "inside" the society (though proclaiming at the same time the importance of spatial factors when forming combinations of social phenomena and processes) and it leads to an exchange of geographical examination tasks for sociological, political or possibly economic tasks. Jointly, an ideologization of study is increased, sometimes even deliberately (e.g. Harvey, D., 1974).

The study of the geographical organization of changes and unbalances in "internal" societal situation is crucial for two reasons. First, societal demand for such studies results from the needs of the decision sphere, both at central and local levels. Second, the dynamics of transformation changes, which increases the attractiveness of their study. It can be seen, generally, that the changeability of social and especially economic conditions is greater in the period of transformation than the changeability of geographical conditions. For example, Czech population distribution remained very stable after 1989 (in all categories of districts examined in Table 1 the index of shares on the total population of the Czech Republic in 1991 - 1995 was 100), and from the point of view of job distribution the changes were only limited. In such a short period of time, the size hierarchy of cities or areas of regional influence of centres could not change to any notable extent. On the other hand, regional differences in the increase of salaries, even in spite of prominent social policy of government, were great and the differences in the dynamics of privatization processes or economic growth were even greater by orders. All this corresponds to the complex and cumulative character of the conditioning of geographical organization and its changes, due to the important connections to diverse physical structures (housing stock, technical infrastructure) and natural environment.

In spite of the more limited changeability of geographical organization of the society, its role in the "internal" development of society is considerable. This occurs because first, there is an extraordinary extent of differentiation of this organization and thus of different favourableness of "external" conditions of social and economic transformation. It is because of the fundamental societal changes after 1989 that this importance of differentiating and stimulating influence of geographical conditions on societal development arose fundamentally. The potential of existing differences in the quality of geographical conditions was realized gradually in consequence to democratization and transition to the market economy. Thus, in the centre of the research effort of geography should be an assessment of possibilities of effective realization of this potential, finding the ways how to remove barriers to both spontaneous selective processes (see e.g. underdevelopment of housing market) and the 
ways how to suitably support cooperative processes (deepening territorial distribution of labour), diffusion of innovations, etc. Only after seeing the solution to these problems can it be justified to discuss special questions how to realize social and economic transformation, questions dealing with regional policy, the influence of macroeconomic policy on regional development, etc.

Although in the first phase of transformation especially differentiating influence of geographical organization on the course of internal societal changes is dominant, it is without any doubt that new tendencies appear in the development of geographical organization of society itself. Their full expansion can be expected only in the following and longer period. This is because removal of the barriers (e.g. to migration) cannot be realized in the short term. The same is true with deepening the differences in the allocation of resources and labour force demands which will gain importance only after changes in company behaviour which are contingent upon privatization. In spite of all this, certain signs of development of suburban processes, the formation of potential emigration regions, or partial changes in working activity especially in metropolitan areas, can be seen already. Thus, both in the upto-date and in the future development rather limited development of extensive processes and contrarily strengthened development of intensification processes must be expected. Shifts in the distribution of population or jobs will not be much extended, but changes in functional importance of centres and whole regions, in territorial organization of relations and in changes of central places role of the cities may be relatively significant. Their influence and regional importance may first increase at the centres of service and quaternary activities.

At the same time, simultaneous with the opening up of the economy and the linking between elements of the settlement system, integration tendencies will be strengthened. In the basic skeleton of the settlement system two or three interlinked trends have appeared already. First, there is a partial substitution of a traditionally quantitative (size) hierarchy of centres by qualitative (functional importance) hierarchy. Second, the hierarchic polarization (centre - periphery) move gradually to higher rank/scale levels. In the conditions of the Czech Republic, this is the case of higher regional levels in the context of the national system (Prague metropolitan region - other metropolitan regions - non-metropolitan areas) and the case of supranational level (integration into European system of centres and axes).

\section{Conclusion: is uneven development a problem or a regularity?}

A discussion about the problem of uneven development of the society is in the centre of interest of many geographer's works with theoretical or application orientation. This discussion is usual starting point for assessments of development of the society, creation of different regulative conceptions of "improvement" of spontaneous processes, etc. Uneven development is in them generally considered before all as a social problem, as an undesirable creating or deepening of social unbalances. The authors with marxist orientation even explain uneven development by means of political and economic nature of capitalism and in this sense they connect it only with the capitalist system (Smith, N., 1990). This opens possibilities for confusing conditionality of the development of internal and external organization of the society, confusing the real and the normative evaluations. 
Starting point for the discussion should be putting the problem of uneven development into general context. First, it is necessary to refer to general predominance of selective tendencies in development not only of the geographical organization of the society but in the development of the environmental or integral systems in general. Evolution of qualitative differentiation of reality has of an extremely selective character: from quantity of the lower the "few" higher arise; spatial occurrence of a locale with allotment of evolutionary higher phenomena is extremely limited and is furthermore internally differentiated in an extraordinary manner (for example the limited extent of the ecumena, the scarce occurrence of great concentrations of progressive economic activities in its context, etc.). All this allows one to accept the conclusion about universal validity and regular nature of "uneven development" of real systems of integral (complex) type. Development of the society in an environment introduces more complexity, and for that reason specific forms of selective processes. The "internal" and "external" organization of society must be understood as having certain coordinating and mediating structures in an interaction between relatively homogeneous mankind and its external, extremely heterogeneous environment. In the formation of external organization of the society, selective processes are necessary, not only because of an adaptation to external differences in the suitability of environment, but also because of societal activity leading to the creation of new forms of territorial division of labour (see especially advantages of the territorial concentration and corresponding nodal organization of socio-geographical regions). Owing to selective or concentration processes the grade of unevenness in geographical distribution of societal phenomena is more intensive than that of natural phenomena. At the same time, extreme unevenness is mostly found only from the point of view of territorial intensity of phenomena occurrence (e.g. density of population). From the point of view of quality of life represented in a simplified way by the "income per capita" this unevenness is considerably lower. Connections between both types of unevenness are immediate: more effective geographical distribution of population can be realized only by means of a corresponding increase in the standard of living.

As a matter of fact, the regular nature of "uneven development" makes absurd its assessment from the social justice point of view. This can deal only with the results of development. With respect to their complex character, the assessments of different partial results will be of course different. On the one hand, the profitability of efficient elements will be raised, but in addition, the economic force of the whole system will be raised, too. That is why in transformation or dynamic periods, an accentuation of selective processes can be found. The acceleration of development by means of an increased selectiveness usually brings about a lot of more profound though not immediately evident advantages, even for the inefficient elements. These include the deepening of territorial division of labour, finding more suitable specialization for most elements of the system, and the ensuing development of cooperative processes in the whole system.

On the other hand, one may also encounter a deepening of social differences and polarization of the rich and the poor. Excessive unevenness of such types increases possibilities of social destabilization, the rising of populist political representations, or even social revolution. From the strategic angle of view it is desirable to maintain social stability. Another danger of disorders in societal evolution comes from the possibility of monopolizing economic power, which would restrict the market as a key mechanism of selection. It 
stands to reason that favourable societal development depends to a considerable extent on ensuring proportionality in enforcing both selective and homogenizing processes, on creating a suitable extent of respecting meritocracy principles and solidarity principles. Necessary autoregulative mechanisms for finding the mentioned proportionality are already built in spontaneous societal development: for example the distribution of activities and deepening of specialization of the parts, the migration of the population which mostly enforces differences in settlement intensity but at the same time reduces differences in income of people due to their transfer into better paid sectors, richer regions, etc. Prevalence of cumulative tendencies in development (cf. e.g. Myrdal, G., 1957, Richardson, H. W., 1978) makes it necessary to direct aid to the poor. The degree of regulation and extent of redistribution must be decided politically.

The question of the degree of regulation cannot be solved at only one level. There will always be the question of a set of different regulative measures, so the key issue lies in their selection and chosen forms of application. It is very desirable to take into account the above discussed systemic nature of society and its development, and the role of dynamizing and stabilizing processes. The experiences of West European countries evoke a transition from simple donation policy to mobilizing policy. This calls for a necessary decentralization of power and existence of complex subjects of territorial development. However, on the contrary, there has been several years of postponing selfgoverning provinces in the Czech Republic. Indeed, it is not always just the question of regulation for underdeveloped units. One example is the state of housing in the Czech Republic, where support for housing construction would help not only to solve the situation of certain population groups (especially young families), but also to remove barriers of selective spatial mobility of the labour force (the deregulation of rent is necessary at the same time). Generally, the advantage of aid in the spheres which are connected with the development of (territorial) division of labour should be stressed. These spheres help to increase the interlinkage of the whole system (technical infrastructure, etc.), which supports the spread of innovations and economic cooperation.

\section{References:}

BHASKAR, R. (1979): The Possibility of Naturalism: A Philosophical Critique of the Contemporary Human Sciences, Harvester, Brighton, $228 \mathrm{p}$.

BLAŽEK, J. (1994): Local financing and settlement structure. In: M. Barlow, P. Dostál, M. Hampl (eds.), Territory, Society and Administration. The Czech Republic and the Industrial Region of Liberec. University of Amsterdam, Amsterdam, pp. 85-94.

CARTER, F. W., MAIK, W. eds. (1995): Proces przekształceń społeczno-gospodarczych w Europie środkowej i wschodniej po roku 1989. Turpress, Toruń, $164 \mathrm{p}$.

DOSTÁL, P., HAMPL, M. (1995): Geographical organization and societal development: searching for an integral approach. Acta Universitatis Carolinae - Geographica, vol. 30 (in print).

GIDDENS, A. (1984): The Constitution of Society. Polity Press, Cambridge, 402 p.

HÄGERSTRAND, T. (1973): The domain of human geography. In: R. J. Chorley ed,, Direction in Human Geography, Methuen, London, pp. 67-87.

HÄGERSTRAND, T. (1995): Landscape as Overlapping Neighbourhoods. In: G. B. Benko, U. Strohmayer (eds.), Geography, History and Social Sciences. Kluwer Academic Publishers, Dordrecht - Boston - London, pp. 83-96.

HAMPL, M. (1994): Territory, Society and Geographical Organization: The Problem of Integral Knowledge. GeoJournal, vol. 32, No. 3, pp. 191-198. 
HAMPL, M. (1995): Geographical Systems and the Order of Reality. In: G. B. Benko, U. Strohmayer (eds.), Geography, History and Social Science. Kluwer Academic Publishers, Dordrecht - Boston - London, pp. 71-80.

HAMPL, M. (1996): Regional development: theoretical conception and specific problems in the Czech Republic. In: Transformation Processes of Social and Economic Regional Systems in the Slovak and the Czech Republic. Acta Geographica Universitatis Comeniae, Bratislava (in print).

HAMPL, M. et al., (1996): Geografická organizace společnosti a transformační procesy v České republice. Univerzita Karlova, Praha (in print).

HARVEY, D. (1974): Population, resources and the ideology of science. Economic Geography, vol. 50, pp. 256-277.

MYRDAL, G. (1957): Economic Theory and Under-Developed Regions. Duckworth, London, $168 \mathrm{p}$.

RICHARDSON, H. W. (1978): Regional and Urban Economics. Penguin, London and New York, $424 \mathrm{p}$.

SAYER, A. (1984): Method in Social Science. A Realist Approach. Huntchinson, London, 313 p.

SAYER, A. (1991): Behind the locality debate: deconstructing geography's dualism. Environment and Planning A, vol. 23, pp. 283-308.

SMITH, N. (1990): Uneven Development, Nature, Capital and the Production of Space. Second ed., Blackwell, Oxford, 219 .

THRIFT, N. (1983): On the determination of social action in space and time. Environment and Planning D, No. 1, pp. 23-57.

\section{Shrnutí}

\section{GEOGRAFIE SPOLEČENSKÉ TRANSFORMACE: OBECNÉ OTÁZKY STUDIA}

Hlavním cílem př́íspěvku je diskuse několika závažných teoretických problémů geografického studia společnosti a jejího vývoje. Diskuse je uskutečněna ve spojitosti s empirickým postižením reálného vývoje sociální a ekonomické regionální diferenciace v České republice po roce 1989. Tento vývoj je ovšem charakterizován již v generalizované úrovni, aby mohl plnit úlohu určité ilustrace nebo dokonce verifikace teoretických závěrů. Na prvém místě je řešena otázka povahy geografických pravidelností. Zdůrazněn je především jejich specifický obsah - pravidelnosti $v$ diferenciaci jevů, jejich kombinací a jejich rozmístění - a jejich rámcová povaha: pravidelnosti nacházíme $\mathrm{v}$ prvé řadě $\mathbf{v}$ celkovém (hierarchickém) uspořádání geografických systémů podle významově primárních znakủ jeho prvkủ (např. velikost sídel, výskyt progresívních aktivit). Naopak v dílčích subsystémech a u speciálních - sekundárně významných - charakteristik geografických jevů existuje značná a více méně nepravidelně uspořádaná variabilita. Na druhém místě je diskutována otázka vztahu společenské a geografické reality. Klíčový význam je přikládán specifikaci vnitřní (sociální, ekonomické apod.) organizaci společnosti na jedné straně a její organizaci vnější (geografické, event. geoekologické) na straně druhé. Z této specifikace vyplývají i funkce obou organizací $v$ integrálním vývoji společnosti. V př́ípadě vnější - geografické organizace je to především funkce diferencující, vyvolávající vývojové podněty, selektivní procesy apod. Ty současně podmiňují prohlubování celkové dělby práce, specializace částí apod. $\mathrm{Z}$ tohoto pohledu je posuzován i třetí diskutovaný problém tzv. nerovnomèrného vývoje společnosti. Na místo častého pojímání tohoto vývoje jako dủsledku bử nesprávné ekonomické, sociální a regionální politiky nebo dokonce nespravedlivého společenského systému je dokládána zákonitá podstata nerovnoměrného vývoje. V̌̌eobecnou snahou celého sledování je předmětovè specifikovat sociální geografii a její poznávací úlohy a zpochybnit dnes módní nahrazování geografických problémủ problémy více méně sociologickými, politickými, event. i ekonomickými.

(Author is with Dpt. of Social Geography and Regional Development, Faculty of Science, Charles University, Albertov 6, 12843 Praha 2.)

Arrived to the editor's office on February 16, 1996 Recommended for publication by Jiři Blažek and Václav Gardavský 